\title{
A Comparison of the Relationship between the Golden Ratio and Anatomical Characteristics of the Supraorbital Foramen in Bare Skulls Belonging to the Byzantine Era and Modern Era
}

\author{
Comparación de la Relación entre la Proporción Áurea y las Características Anatómicas \\ del Foramen Supraorbitario en Cráneos de la Época Bizantina y la Edad Moderna
}

Bakirci S."; Kafa I. M.**; Coskun I.**; Buyukuysal M. C. ${ }^{* * * *} \&$ Barut C. ${ }^{* * * *}$

BAKIRCI, S.; KAFA, I. M.; COSKUN, I.; BUYUKUYSAL, M. C. \& BARUT, C. A comparison of the relationship between the golden ratio and anatomic characteristics of the supraorbital foramen in bare skulls belonging to the byzantine era and modern era. Int. $J$. Morphol., 34(2):671-678, 2016.

SUMMARY: The aim of the present study is to determine the frequency of the occurrence of supraorbital foramen/notch (SOF/ $\mathrm{N}$ ) in the skulls of the people who lived in the modern era and the late Byzantine era, to determine the symmetry and the asymmetry between the two halves of the skulls by measuring the linear distance to various landmarks, to check the consistency between the location of the SOF/N and the golden ratio by calculating the ratio between linear distances and to evaluate the differences between the skulls from both historical periods. In the study, the frequency of the occurrence of the supraorbital notch in the skulls from the Byzantine era was found to be $26.60 \%$ on the right and $13.30 \%$ on the left while it was $14.30 \%$ on the right and $9.52 \%$ on the left in the skulls belonging to modern humans. In the skulls belonging to the Byzantine era, the average distance between SOF/N and the sagittal axis passing along the lateral orbital wall was found to be $34.81 \pm 2.51 \mathrm{~mm}$ and $32.99 \pm 2.81 \mathrm{~mm}$ respectively on the right and the left while it was $33.14 \pm 2.19 \mathrm{~mm}$ and $33.39 \pm 2.06 \mathrm{~mm}$ in the skulls belonging to modern era. The average distance between the SOF/N and the sagittal plane passing along the midline of the skull was found to be $24.55 \pm 2.79 \mathrm{~mm}$ and $21.57 \pm 2.44 \mathrm{~mm}$ on the right and the left respectively in the skulls belonging to the Byzantine era while it was $0.04 \pm 3.30 \mathrm{~mm}$ and $20.96 \pm 2.37 \mathrm{~mm}$ in the skulls belonging to the modern era. The average distance between the $\mathrm{SOF} / \mathrm{N}$ and sagittal plane passing along the medial orbital wall was found to be $23.78 \pm 3.60 \mathrm{~mm}$ and $23.81 \pm 3.20 \mathrm{~mm}$ on the right and the left respectively in the skulls belonging to the Byzantine era while it was found to be $22.23 \pm 3.29 \mathrm{~mm}$ and $23.97 \pm 1.93 \mathrm{~mm}$ in the skulls belonging to the modern era. The average value of the distance between the sagittal planes passing along the lateral and medial sides of the orbit and the ratios between the distance from SOF/N to the sagittal plane passing along the lateral side of the orbit was found to be $1.47 \pm 0.21 \mathrm{~mm}$ and $1.60 \pm 0.08 \mathrm{~mm}$ respectively in the skulls belonging to the Byzantine era and the modern era. No significant difference was found between this ratio and the golden ratio; the average value of the ratios between the distance from the SOF/N to the sagittal plane passing along the midline of the skull and the distance from the SOF/N to the sagittal plane passing along the lateral side of the orbit was found to be $0.98 \pm 0.26 \mathrm{~mm}$ and $1.04 \pm 0.36 \mathrm{~mm}$ respectively in the skulls belonging to the Byzantine era and the modern era. A significant difference was found between this ratio and the golden ratio for both historical periods (modern society and late Byzantine period) $(\mathrm{p}<0.005)$. The comparison of the relevant anatomic characteristics of the SOF/N is very important for anthropologists while a broad knowledge on proportional calculations regarding morphometric values and the location are important for reconstructive surgeons and the experts in forensics and pain control.

KEY WORDS: Supraorbital foramen; Supraorbital notch; Golden ratio; Byzantine era; Asymmetry; Frontal bone.

\section{INTRODUCTION}

The foramens and the notches on bones are crucial anatomic orientation points. It is necessary to know the anatomic characteristics, morphometric values and the variational spectrum of these structures well, so that the veins and the nerves passing along these foramens and notches are not damaged, the success rate in local anesthesia is high and the surgeons do not encounter any complications during facial surgery. SOF/N is located in the frontal bone, below

\footnotetext{
Department of Anatomy, School of Medicine, Düzce University, Duzce, Turkey.

** Department of Anatomy, School of Medicine, Uludag University, Bursa, Turkey.

*** Department of Biostatistics, School of Medicine, Bülent Ecevit University, Zonguldak, Turkey.

***** Department of Anatomy, School of Medicine, Bahcesehir University, Istambul, Turkey.
} 
the superciliary arch and the upper side of the orbit. The lateral branch of the supraorbital nerve, which is the terminal branch of the frontal branch of the ophthalmic nerve, passes through the SOF/N. It carries sensory fibers. Thus, $\mathrm{SOF} / \mathrm{N}$ is used as a point to apply pressure for the trigeminal nerve (Williams et al., 1989). The supraorbital nerve frontal sinus, conjunctiva and the skin on the forehead are innervated with $2 / 3$ of the scalp. A fairly comprehensive anatomical knowledge on the $\mathrm{SOF} / \mathrm{N}$ is necessary in flap reconstructions used in upper eyelid lift surgeries (blepharoplasty) and forehead surgeries. The frequency of the occurrence of SOF/ $\mathrm{N}$ in the shape of foramen and notch varies considerably in different populations (Rehman et al., 2012; Tomaszewska et al., 2012; Ilayperuma et al., 2014). Symmetry is an indication of beauty and attractiveness in the human face and there are many studies on sex and age-related changes in the face (Ferrario et al., 1994; Ferrario et al., 2001; Baudouin \& Tiberghien, 2004; Zaidel \& Cohen, 2005). As a result of the analyses of face models, it was demonstrated that many anatomic landmarks were asymmetric and the left side was dominant in the Turkish society (Ercan et al., 2008).

The golden ratio, also known as divine ratio, is equal to approximately 1.618. It is believed that this ratio is used in the design of many things in the universe in terms of aesthetics and consistency. This aesthetic ratio is also seen in many structures in the human body; for example between the length and width of the human face, between the sum of the width and the height of the two central incisor teeth, between the length of the first two phalanx and the length of fingers and between the structures forming the lung (Prasanth, 2012). In the study carried out by I'kiz (1999) on Byzantine skulls, the variations of the SOF/N and its relationship with the intraorbital foramen were investigated. Based on this study and considering the demonstration of presence of the golden ratio in many anatomic structures, the question of whether there was a relationship between the location of the supraorbital foramen and the golden ratio, which is the subject of the present study, came to the forefront. In the present study, the data on the morphometric measurements of the $\mathrm{SOF} / \mathrm{N}$ in the skulls belonging to the people who lived in the modern era and the Byzantine era in the same region were compared and the similarity between the location of the SOF/N and the golden ratio was examined.

\section{MATERIAL METHOD}

Thirty eight human skulls were provided from the Anatomy Department of the Faculty of Medicine of Uludag University. Twenty-one of the skulls used in the present study belonged to the modern era while 17 were from the late Byzantine era. The latter ones were obtained from the archeological site named "Nicea" in Iznik district of Bursa in 1984. The morphological measurements on these skulls, where the lateral and lower sides of the orbit were fractured, were not taken within the scope of the evaluation. Digital photos were obtained with a Canon 450D digital camera in standard positions with appropriate photographic techniques prior to the digital measurements (Barut \& Ertilav, 2011). In digital photos, the measurements of 6 parameters were performed on each of the two halves of the skulls (Fig. 1, Table I). The distances from the SOF to sagittal planes passing along the lateral and medical sides of the orbit and the midline of the skull and to the infraorbital side were measured respectively. Also, the distance between the SOF and the sagittal planes passing along infraorbital foramen (IOF) was measured.

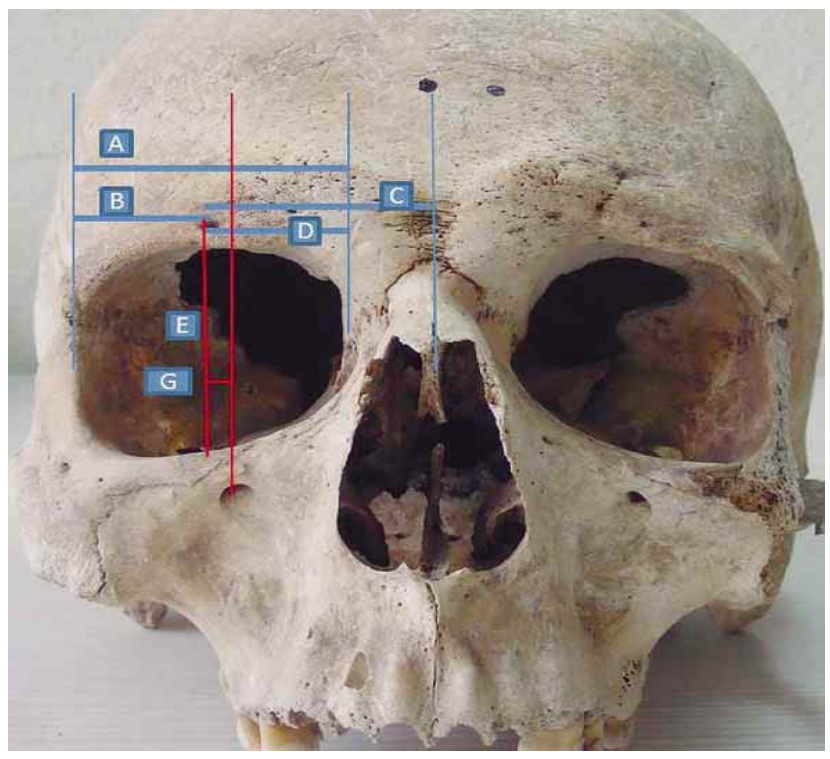

Fig. 1. Parameters (six, A-G) used in the morphological measurements on each side of the skulls.

Table I. Parameters used and its definition for the morphological measurements in the skulls.

\begin{tabular}{ll}
\hline & Distances are measured to infraorbital foramen \\
\hline A & Distances between the sagittal planes passing through medial and lateral side of the orbit. \\
B & Distances from the $\mathrm{SOF} / \mathrm{N}$ to the sagittal plane passing through lateral side of the orbit. \\
C & Distances from the $\mathrm{SOF} / \mathrm{N}$ to the midsagittale plane of the cranium \\
$\mathrm{D}$ & Distances from the $\mathrm{SOF} / \mathrm{N}$ to the sagittal plane pas sing through medial side of the orbit. \\
$\mathrm{E}$ & Distances from the $\mathrm{SOF} / \mathrm{N}$ to the inferior side of the orbit. \\
$\mathrm{G}$ & Distances between the sagittal planes passing through $\mathrm{SOF} / \mathrm{N}$ and IOF
\end{tabular}


The golden ratio was sought in i) the distance between the sagittal planes passing along the lateral and medial sides of the orbit and the distance from the SOF to the sagittal plane passing along the lateral side of the orbit $(\mathrm{A} / \mathrm{B})$, ii) the distance from the SOF to the sagittal plane passing along the midline of the skull and the distance from the SOF to the sagittal plane passing along the lateral side of the orbit $(\mathrm{C} / \mathrm{B})$, iii) the distance from the SOF to the sagittal plane passing along midline of the skull and the distance from the SOF to sagittal plane passing along the medial side of the orbit (C/D), iv) the distance from the SOF to the sagittal plane passing along the lateral side of the orbit and the distance from the SOF to the sagittal plane passing along the medial side of the orbit (B/D).

The values belonging to the measured parameters were compared between the right and the left sides and the two historical periods; the resulting ratios were evaluated statistically in terms of their relation with the golden ratio. Parameters were measured digitally from digital photographs using Scion Image Software (ver.4.0.3.2).

Statistical Method: The statistical analyses of the study were carried out with SPSS 19.0. The descriptive statistics of the continuous variables in the study were demonstrated with median, minimum, maximum, average values and standard deviation. The normality was assessed using the ShapiroWilk test. The consistency of the measurements with the golden ratio was evaluated with the Wilcoxon single sample test and "BlandAltman" method. In the comparison of two independent groups, Mann Whitney $\mathrm{U}$ and independent sample $t$ tests were used. The presence of a difference between the right and left side measurements was checked using paired samples $t$ test. Among all statistical comparisons within the study, the ones where the $\mathrm{p}$ value remained under 0.05 were considered to be statistically significant.

\section{RESULTS}

The descriptive statistical data regarding the SOF measurements on the bare skulls belonging to the late Byzantine era and the modern era, median, minimum, maximum, average and standard deviation values are given on Table II.

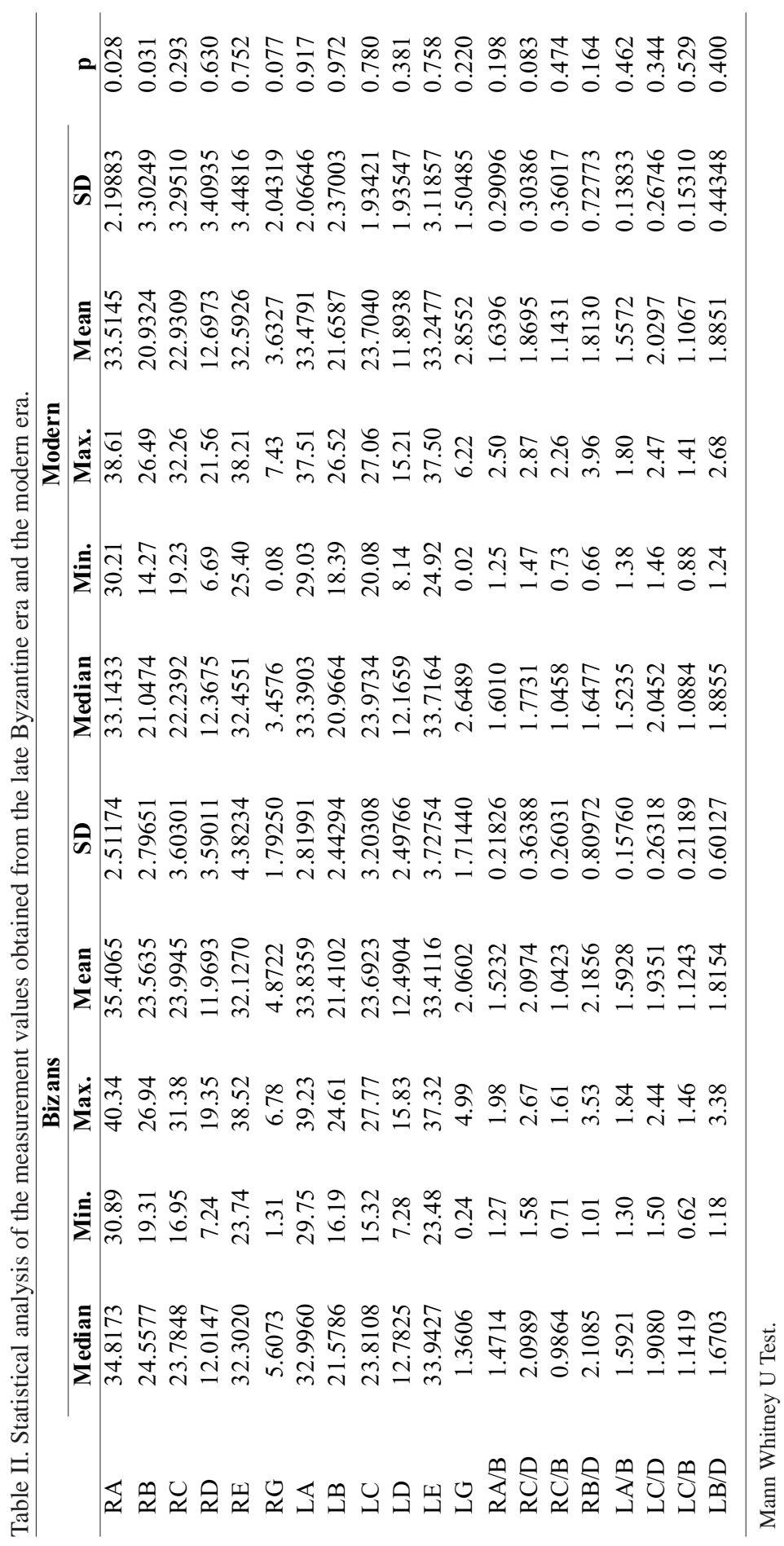

There was a significant difference only between RA (A parameter being the right side) and RB (B parameter being the left side) values between the two groups. The mentioned parameters were higher in the bone samples from the Byzantine era and the difference was statistically significant $(p=0.028$ and $p=0.031)$. No 
other statistically significant difference was found between the two groups when other measurement parameters were evaluated $(\mathrm{p}>0.05)$

As there was not a significant difference between the samples from the Byzantine era and the modern era (except for A and B samples), the right - left side evaluations were carried out by examining all the skulls used in the study as one group. E and G parameters were higher on the right in comparison to the left and the difference was statistically significant $(\mathrm{p}<0.05)$. When the other parameters were evaluated according to location on the body, there was no statistically significant difference found between the right and the left sides ( $p$ $>0.05$ ). In this case, it can be said that the measurement values obtained from the right and the left sides were similar and this situation can be evaluated in favor of symmetry.

With regards to the relation between the golden ratio and the aforementioned ratios, the following can be said: As no significant difference was found among the samples from the modern era (except for A and B parameters), all skulls included in the study were evaluated as a single group. It was determined that there was a significant difference among $\mathrm{C} / \mathrm{D}, \mathrm{C} / \mathrm{B}, \mathrm{B} / \mathrm{D}$ ratios among the ratios obtained from both sides (right and left) and the golden ratio ( $\mathrm{p}<0.05$ ) while the difference between $\mathrm{A} / \mathrm{B}$ ratio and golden ratio was not statistically significant for the right and the left side $(\mathrm{p}>0.05)$. This indicates that $\mathrm{A} / \mathrm{B}$ ratio is similar to the golden ratio both on the right and the left side and there is no significant difference between them (Table IV and Fig. 2, Bland-Altman method).

\section{DISCUSSION}

Detailed anatomy of the forehead area, its vascular nourishment and variations are important in forehead flap procedures administered by reconstructive surgeons and in upper eyelid lift surgeries performed by orbitomaxillary surgeons (Kleintjes et al., 2007; Chavan \& Shende, 2013). Supraorbital artery is the branch sprout from ophthalmic artery while it is progressing forward from the medial of the optic nerve and goes upwards from the medial of the superior rectus muscle and then, joins supraorbital nerve between the elevating muscle of upper eyelid (levator

Table III. Comparison of the values and ratios obtained from the right and the left sides.

\begin{tabular}{|c|c|c|c|c|c|c|c|c|c|c|c|}
\hline & \multicolumn{5}{|c|}{ Sa } & \multicolumn{5}{|c|}{ Sol } & \multirow[b]{2}{*}{ p } \\
\hline & Median & Min. & Max. & Mean & SD & Median & Min. & Max. & Mean & SD & \\
\hline $\mathrm{A}$ & 34.2091 & 30.21 & 40.34 & 34.2713 & 2.47802 & 33.3665 & 29.03 & 39.23 & 33.6155 & 2.34747 & 0.134 \\
\hline $\mathrm{B}$ & 21.8786 & 14.27 & 26.94 & 21.9849 & 3.33406 & 21.0190 & 16.19 & 26.52 & 21.5637 & 2.36421 & 0.631 \\
\hline $\mathrm{C}$ & 23.6947 & 16.95 & 32.26 & 23.3563 & 3.41027 & 23.9671 & 15.32 & 27.77 & 23.6995 & 2.44912 & 0.364 \\
\hline $\mathrm{D}$ & 12.2752 & 6.69 & 21.56 & 12.4061 & 3.44913 & 12.2527 & 7.28 & 15.83 & 12.1219 & 2.15069 & 0.615 \\
\hline $\mathrm{E}$ & 32.4551 & 23.74 & 38.52 & 32.4063 & 3.79350 & 33.9400 & 23.48 & 37.50 & 33.3122 & 3.31535 & 0.019 \\
\hline G & 4.6198 & 0.08 & 7.43 & 4.1363 & 2.01252 & 2.6289 & 0.02 & 6.22 & 2.5475 & 1.60978 & 0.011 \\
\hline $\mathrm{A} / \mathrm{B}$ & 1.5459 & 1.25 & 2.50 & 1.5931 & 0.26714 & 1.5748 & 1.30 & 1.84 & 1.5708 & 0.14470 & 0.650 \\
\hline $\mathrm{C} / \mathrm{D}$ & 1.8672 & 1.47 & 2.87 & 1.9607 & 0.34317 & 1.9579 & 1.46 & 2.47 & 1.9935 & 0.26593 & 0.466 \\
\hline $\mathrm{C} / \mathrm{B}$ & 1.0422 & 0.71 & 2.26 & 1.1028 & 0.32361 & 1.1084 & 0.62 & 1.46 & 1.1134 & 0.17495 & 0.830 \\
\hline $\mathrm{B} / \mathrm{D}$ & 1.7979 & 0.66 & 3.96 & 1.9620 & 0.77235 & 1.7178 & 1.18 & 3.38 & 1.8584 & 0.50184 & 0.534 \\
\hline
\end{tabular}

Paired samples $t$ test. The ratios between the measured distances belonging to both periods, the statistical comparison of $\mathrm{A} / \mathrm{B}, \mathrm{C} / \mathrm{D}, \mathrm{C} / \mathrm{B}, \mathrm{B} / \mathrm{D}$ ratios with the golden ratio are given on Table IV and Figure 2 (Bland-Altman).

Table IV. The relation between the ratios obtained regarding the supraorbital foramen and the golden ratio.

\begin{tabular}{lccccccc}
\hline & Median & Minimum & Maximum & Mean & SD & Altın Oran & p \\
\hline RA/B & 1.5459 & 1.25 & 2.50 & 1.5931 & 0.26714 & 1.618 & 1.618 \\
RC/D & 1.8672 & 1.47 & 2.87 & 1.9607 & 0.34317 & $<4$ \\
RC/B & 1.0422 & 0.71 & 2.26 & 1.1028 & 0.32361 & 1.618 & $<0.001$ \\
RB/D & 1.7979 & 0.66 & 3.96 & 1.9620 & 0.77235 & 1.618 & 0.027 \\
LA/B & 1.5748 & 1.30 & 1.84 & 1.5708 & 0.14470 & 1.618 & 0.052 \\
LC/D & 1.9579 & 1.46 & 2.47 & 1.9935 & 0.26593 & 1.618 & $<0.001$ \\
LC/B & 1.1084 & 0.62 & 1.46 & 1.1134 & 0.17495 & 1.618 & $<0.001$ \\
LB/D & 1.7178 & 1.18 & 3.38 & 1.8584 & 0.50184 & 1.618 & 0.016 \\
\hline
\end{tabular}

One-sample Wilcoxon Signed Rank Test. 
BAKIRCI, S.; KAFA, I. M.; COSKUN, I.; BUYUKUYSAL, M. C. \& BARUT, C. A comparison of the relationship between the golden ratio and anatomic characteristics of the supraorbital foramen in bare skulls belonging to the byzantine era and modern era. Int. J. Morphol., 34(2):671-678, 2016.
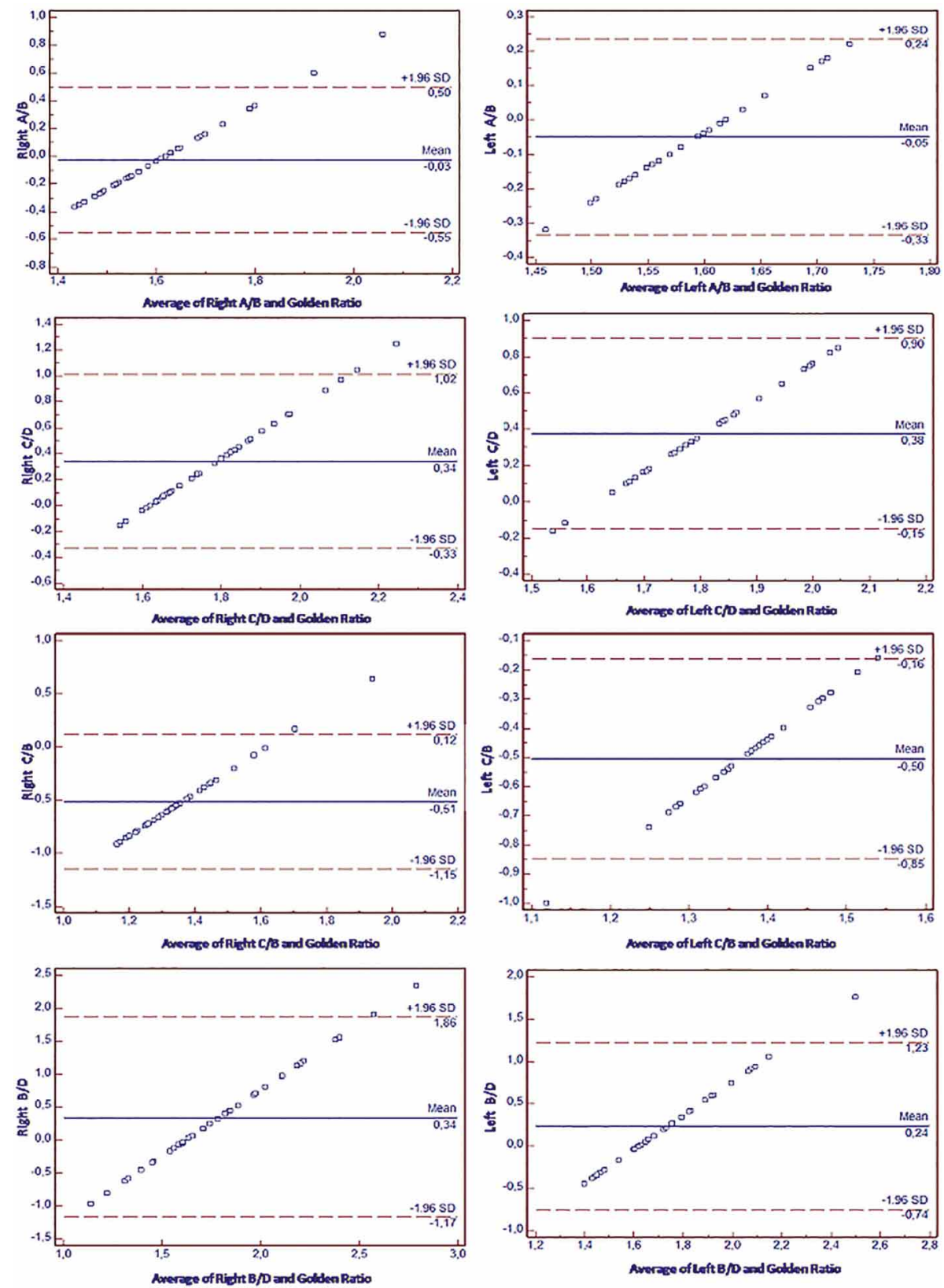

Fig. 2. Distribution graphs of ratio values against golden ratio (Bland and Altman).

palpebra superior) and orbit, goes straight and passes along $\mathrm{SOF} / \mathrm{N}$. It has two sub branches named superficial and deep branches. It is responsible for nourishing the upper eyelid, frontal bone and frontal sinus. Detailed anatomic characteristics of the SOF/N and the variations of its morphometric values in different populations should be known well and comprehensively.

The variations of the foramen supraorbitalis were evaluated before in the study by Ikiz on bare skulls belonging to the Byzantine era and it was concluded that the supraorbital foramen was seen as a foramen by $20.0 \%$ on the right and $12.5 \%$ on the left and as a notch by 73.3 $\%$ on the right and $85.4 \%$ on the left (with the name 'incisura supraorbitalis'). In the same study, it was found that it was seen both as a foramen and a notch by $6.7 \%$ on the right and $2.1 \%$ on the left and there was no orbita without incisura or supraorbital foramen. The skulls showing variations both in the shape of a foramen and a notch were not taken within the scope of the present study. 
BAKIRCI, S.; KAFA, I. M.; COSKUN, I.; BUYUKUYSAL, M. C. \& BARUT, C. A comparison of the relationship between the golden ratio and anatomic characteristics of the supraorbital foramen in bare skulls belonging to the byzantine era and modern era. Int. J. Morphol., 34(2):671-678, 2016.

In the study by Mishra et al. (2013) carried out in India, it was reported that the frequency of occurrence of the supraorbital notch in the shape of foramen was 28.57-28.14 $\%$ on the right and the left respectively in men while it was $50.94-45.28 \%$ in women. It is seen that the frequency of the occurrence in shape of foramen can be considered equal for the right and the left sides both in men and women. The ratio was found to be $26.60 \%$ on the right and $13.30 \%$ on the left in the skulls belonging to the Byzantine era while it was $14.30 \%$ on the right and $9.52 \%$ on the left in the skulls belonging to the modern era. The frequency of occurrence in the shape of foramen is more on the right side both in the Byzantine and the modern era. This similarity leads to the assumption that two societies living in different historical periods in the same region did not change a lot in time and in fact they complement one another. Tomaszewska et al., studied the frequency of the occurrence of supraorbital foramen in the skulls of the people who lived in three different climatic zones in Poland and reported the ratio to be $35.4 \%$ for the zone with a cold climate, $18.8 \%$ for zones with a hot climate and $19.9 \%$ for the zones with a temperate climate. In 2014, Ilayperuma et al., found the frequency of the occurrence of supraorbital foramen in the skulls in Sri Lanka to be $35.19 \%$. In the study carried out by Woo et al. (2013) in Korea on 3D-CT images, the frequency of the occurrence of single supraorbital foramen was found to be $37 \%$ and $42.3 \%$ for the right and the left sides respectively. In the present study, the average distance between $\mathrm{SOF} / \mathrm{N}$ and the sagittal plane passing along the midline of the skull was found to be $24.55 \pm 2.79$ and $21.57 \pm 2.44 \mathrm{~mm}$ on the right and the left side respectively in the skulls from the Byzantine era while it was $21.04 \pm 3.30$ and $20.96 \pm 2.37 \mathrm{~mm}$ respectively in those from the modern era. When the two groups are evaluated together, 23.69 \pm 3.41 and 23.96 $\pm 2.44 \mathrm{~mm}$ were found for the right and the left sides respectively. A statistically significant difference was not found neither in the samples from the modern era not in those from the Byzantine era, between the right and the left sides. As a result, it was interpreted that supraorbital notches/foramens showed symmetry in the skulls, for both historical periods. Woo et al., determined the distance between the SOF/N and nasion in the 3D-CT images to be $27.58 \pm 4.10$ and $26.81 \pm 3.94$ for the right and the left side respectively, for the total of the women and men skulls. In the study carried out by TurhanHaktanir et al. (2008) on multidetector computed tomography images, the distance between the SOF/N and the midline was found to be $32.36 \pm 1.0$ and $29.16 \pm 0.9 \mathrm{~mm}$ for the right and the left respectively in men and 25.86 \pm 0.9 and $24.66 \pm 0.7 \mathrm{~mm}$ in women and $29.36 \pm 6.1$ and $27.06 \pm 5.2$ $\mathrm{mm}$ in total. In the present study, the average distance between the SOF/N and the sagittal plane passing along the lateral orbital wall was found to be $34.81 \pm 2.51$ and
$32.99 \pm 2.81 \mathrm{~mm}$ for the right and the left respectively in the skulls belonging to the Byzantine era and 33.14 \pm 2.19 and $33.39 \pm 2.06 \mathrm{~mm}$ respectively in those belonging to the modern era. That there is no significant difference between the right and the left sides for both historical periods in these results was considered as another indication that the locations of the SOF/Ns in the skulls were symmetrical.

When the ratios between the SOF/N and the relevant measured distances were examined in the present study, it was determined that $\mathrm{A} / \mathrm{B}, \mathrm{C} / \mathrm{D}, \mathrm{C} / \mathrm{B}, \mathrm{B} / \mathrm{D}$ ratios were $1.54 \pm 0.26 \mathrm{~mm}, 1.86 \pm 0.34 \mathrm{~mm}, 1.04 \pm 0.32 \mathrm{~mm}, 1.79 \pm 0.77$ $\mathrm{mm}$ respectively for the right side and $1.57 \pm 0.14 \mathrm{~mm}$, $1.95 \pm 0.26 \mathrm{~mm}, 1.10 \pm 0.17 \mathrm{~mm}, 1.71 \pm 0.50 \mathrm{~mm}$ for the left side (Table IV). When these ratios were compared to the golden ratio, it was seen that there was not a significant difference between $\mathrm{A} / \mathrm{B}$ ratio and the golden ratio in the right and the left sides $(p>0.05)$ while there was a significant difference ( $p<0.05$ ) between the other 3 ratios and the golden ratio. This indicates that the distance between the sagittal planes passing along the lateral and medial sides of the orbit and the ratio of the distance from the $\mathrm{SOF} / \mathrm{N}$ to the external orbital wall are consistent the golden ratio. In the present study, the distance between $\mathrm{SOF} / \mathrm{N}$ and the planes passing along the IOF was checked (G parameter). The average value of the $\mathrm{G}$ parameter was found to be $5.60 \pm 1.79$ and $1.36 \pm 1.71$ $\mathrm{mm}$ respectively for the right and the left sides in the skulls belonging to the Byzantine era while it was found to be $3.45 \pm 2.04$ and $2.64 \pm 1.50 \mathrm{~mm}$ for those belonging to the modern era. When the average values of the $G$ parameter belonging to both historical periods (Byzantine and Modern society) were compared, no significant difference was found. However, when all the data about the skulls were brought together, the average $G$ value between the right and left sides was found to be $4.61 \pm 2.01$ and $2.62 \pm 1.50 \mathrm{~mm}$ and it was statistically demonstrated that there was a significant difference between the two sides $(\mathrm{p}=0.001)$. This indicates that these two foramens are further from each other on the right in the people from both the Byzantine era and the modern era, considering the locations of the SOF/Ns and IOFs on the sagittal plane. For both historical periods, the distance from the SOF/N to the midline of the skull showed symmetry and thus, it can be concluded that IOF's are closer to the midline of the skull on the right side.

\section{CONCLUSION}

It can be thought that there being no statistically significant difference between the ratio of the distance from the SOF to the sagittal passing along the lateral side of the orbit and the golden ratio in both right and the left sides can 
be associated with the distribution of nerves and arteries rather than the aesthetical look as this structure remained hidden under the soft tissue. The location, shape, size and number of supraorbital foramen/notch varies among the populations. In the present study, it was demonstrated that the locations were in accordance with the golden ratio in terms of certain parameters in the populations examined. The course and variations of nerves and veins are very important in upper eyelid lift surgeries, in forehead flap procedures, for avoiding complications and tissue rejection and performing local anesthesia successfully and controlling and treating neuralgia. The distances from the SOF/N to the medial and lateral sides of the orbit and the midline of the skull have a wide spectrum and vary considerably from person to person. For this reason, individual patient-based practices may not contribute to determining the average values of the distances. Thus, knowing the ratio of the distance from SOF/N to different anatomic landmarks for every individual and its relation between with the golden ratio may help in attempts to ensure pain control besides helping orbitomaxillary, plastic and reconstructive surgeons determine the location of $\mathrm{SOF} / \mathrm{N}$.

BAKIRCI, S.; KAFA, I. M.; COSKUN, I.; BUYUKUYSAL, M. C. \& BARUT, C. Comparación de la relación entre la proporción áurea y las características anatómicas del foramen supraorbitario en cráneos de la época Bizantina y la edad moderna. Int. J. Morphol., 34(2):671-678, 2016.

RESUMEN: El objetivo fue determinar la frecuencia del foramen y incisura supraorbitaria (FSO/E) en cráneos de individuos de la era moderna y aquellos de la era bizantina, para determinar la simetría y asimetría entre las dos mitades de cráneos, mediante la medición de la distancia lineal a varios puntos de referencia, para comprobar la coherencia entre la ubicación del FSO/ y la proporción áurea, a través del cálculo de la relación entre las distancias lineales. Además, se evaluaron las diferencias entre los cráneos de periodos históricos. En el estudio, se determinó que la frecuencia registrada de la incisura supraorbitaria en los cráneos de la época bizantina fue del $26,60 \%$ en el lado derecho y $13,30 \%$ en el izquierdo; mientras que en cráneos humanos modernos fue de 14,30\% en el lado derecho y $9,52 \%$ en el izquierdo. En los cráneos pertenecientes a la época bizantina, la distancia media entre FSO/E y el eje sagital a lo largo de la pared lateral de la órbita fue de $34,81 \pm 2,51 \mathrm{~mm}$ y $32,99 \pm 2,81 \mathrm{~mm}$, a la derecha e izquierda, respectivamente; mientras que en cráneos de la era moderna fue de $33,14 \pm 2,19 \mathrm{~mm}$ y $33,39 \pm 2,06 \mathrm{~mm}$, a la derecha e izquierda, respectivamente. La distancia media entre la FSO/ E y el plano sagital que pasa a lo largo de la línea mediana del cráneo, en los cráneos de la época bizantina, fue de 24,55 $\pm 2,79$ mm y $21,57 \pm 2,44 \mathrm{~mm}$ a la derecha e izquierda, respectivamente; mientras que fue de $0,04 \pm 3,30 \mathrm{~mm}$ y 20,96 $\pm 2,37 \mathrm{~mm}$ en los cráneos de la era moderna. La distancia media entre la FSO/E y el plano sagital que pasa a lo largo de la pared medial de la órbita, en los cráneos pertenecientes a la época bizantina fue de $23,78 \pm 3,60 \mathrm{~mm}$ y 23,81 $\pm 3,20 \mathrm{~mm}$, a la derecha e izquierda, respectivamente; mientras que en

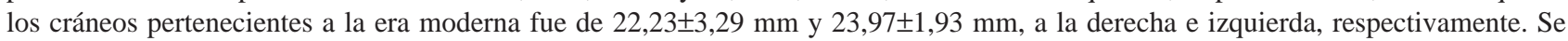
determinó que el valor medio de la distancia entre los planos sagitales a lo largo de los márgenes lateral y medial de la órbita y las

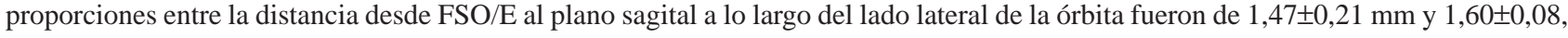
respectivamente, en los cráneos pertenecientes a la época bizantina y la era moderna. No encontramos diferencias significativas entre esta relación y la proporción áurea. El valor medio de las relaciones entre la distancia de la FSO/E al plano a lo largo de la línea mediana

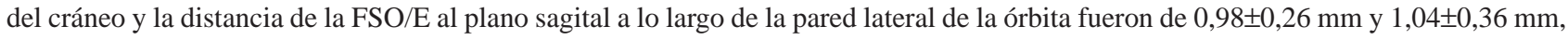
respectivamente, en los cráneos pertenecientes a la era bizantina y la era moderna. No se encontró una diferencia significativa entre esta relación y la proporción áurea en ambos períodos históricos (la sociedad moderna y el periodo bizantino tardío) (p <0,005). La comparación de características anatómicas relevantes para el FSO/E son importantes para los antropólogos, donde un conocimiento integro de cálculos proporcionales con respecto a los valores morfométricos, mientras que para los cirujanos reconstructivos y los expertos en medicina forense es importante su ubicación.

PALABRAS CLAVE: Foramen supraorbitario; Incisura supraorbitaria; Proporción áurea; Era bizantina; Hueso frontal.

\section{REFERENCES}

Barut, C. \& Ertilav, H. Guidelines for standard photography in gross and clinical anatomy. Anat. Sci. Educ., 4(6):348-56, 2011.

Baudouin, J. Y. \& Tiberghien, G. Symmetry, averageness, and feature size in the facial attractiveness of women. Acta Psychol. (Amst.), 117(3):313-32, 2004.

Chavan, W. M. \& Shende, M. R. The study of supraorbital notches and foramina in adult skulls. Int. J. Healthc. Biomed. Res., 1(4):279-83, 2013.
Ercan, I.; Ozdemir, S. T.; Etoz, A.; Sigirli, D.; Tubbs, R. S.; Loukas, M. \& Guney, I. Facial asymmetry in young healthy subjects evaluated by statistical shape analysis. J. Anat., 213(6):663-9, 2008.

Ferrario, V. F.; Sforza, C.; Poggio, C. E. \& Tartaglia, G. Distance from symmetry: a three-dimensional evaluation of facial asymmetry. J. Oral Maxillofac. Surg., 52(11):1126-32, 1994.

Ferrario, V. F.; Sforza, C.; Ciusa, V.; Dellavia, C. \& Tartaglia, G. 
BAKIRCI, S.; KAFA, I. M.; COSKUN, I.; BUYUKUYSAL, M. C. \& BARUT, C. A comparison of the relationship between the golden ratio and anatomic characteristics of the supraorbital foramen in bare skulls belonging to the byzantine era and modern era. Int. J. Morphol., 34(2):671-678, 2016.

M. The effect of sex and age on facial asymmetry in healthy subjects: a cross-sectional study from adolescence to midadulthood. J. Oral Maxillofac. Surg., 59(4):382-8, 2001.

Ikiz, I. Variations of the supraorbital notch or foramen and relationship of the infraorbital foramen. Uludag Univ. Tip Fak. Derg., 26:9-12, 1999.

Ilayperuma, I.; Nanayakkara, G. \& Palahapitiya, N. Supraorbital notch/foramen in Sri Lankan skulls: morphometry and surgical relevance. Int. J. Morphol., 32(2):435-9, 2014.

Kleintjes, W. G. Forehead anatomy: arterial variations and venous link of the midline forehead flap. J. Plast. Reconstr. Aesthet. Surg., 60(6):593-606, 2007.

Mishra, A.; Shrestha, S. \& Singh, M. Varying positions and anthropometric measurement of supraorbital and supratrochlear canal/foramen in adult human skulls. Nepal Med. Coll. J., 15(2):133-6, 2013.

Prasanth, G. N. S. Golden Ratio in Human Anatomy. PhD Thesis. Chittur, Government College Chittur, 2012.

Rehman, F. U. Prenatal morphometric analysis of supraorbital, infraorbital and mental foramina in human foetuses and their clinical correlations to anaesthesia and surgical procedure. Int. J. Anat. Res., 2(2):446-50, 2014.

Tomaszewska, A.; Kwiatkowska, B. \& Jankauskas, R. The localization of the supraorbital notch or foramen is crucial for headache and supraorbital neuralgia avoiding and treatment. Anat. Rec. (Hoboken), 295(9):1494-503, 2012.

Turhan-Haktanir, N.; Aycicek, A.; Haktanir, A. \& Demir, Y. Variations of supraorbital foramina in living subjects evaluated with multidetector computed tomography. Head Neck, 30(9):1211-5, 2008.

Williams, P. L.; Warwick, R.; Dyson, M. \& Bannister, L. H. Gray's Anatomy. 37th ed. Edinburgh, Churchill Livingstone, 1989. pp.337-67.

Woo, S. W.; Lee, H. J.; Nahm, F. S.; Lee, P. B. \& Choi, E. J. Anatomic characteristics of supraorbital foramina in korean using three-dimensional model. Korean J. Pain, 26(2):130-4, 2013.

Zaidel, D. W. \& Cohen, J. A. The face, beauty, and symmetry: perceiving asymmetry in beautiful faces. Int. J. Neurosci., 115(8):1165-73, 2005.

\section{Correspondence to:}

Dr. Sinan Bakirci, MD, Assistant Professor

Duzce University Medical Faculty

Department of Anatomy

Konuralp 81620

Duzce

TURKEY

Phone: +90 3805421100 / 4124

Fax: +90 3805421302

Email: sinanbakirci@duzce.edu.tr

Received: 21-12-2015

Accepted: 05-04-2016 